\title{
Microbial autotrophic and heterotrophic eucaryotes in Antarctic waters: relationships between biomass and chlorophyll, adenosine triphosphate and particulate organic carbon
}

\author{
Christopher D. Hewes ${ }^{1}$, Egil Sakshaug ${ }^{2}$, Freda M. H. Reid ${ }^{3}$, Osmund Holm-Hansen ${ }^{4}$ \\ ${ }^{1}$ Institute of Microbiology and Plant Physiology, University of Bergen, Bergen, Norway \\ ${ }^{2}$ Biological Station, The Museum, University of Trondheim, Bynesveien 46, N-7018 Trondheim, Norway \\ ${ }^{3}$ Institute of Marine Resources, Scripps Institution of Oceanography, University of California, La Jolla, California 92093, USA \\ ${ }^{4}$ Polar Research Program, Scripps Institution of Oceanography, University of California, La Jolla, California 92093, USA
}

\begin{abstract}
Microscopical examination of near-surface eucaryotic microbial populations in circumcontinental waters of Antarctica indicated that nanoplankton $(<20 \mathrm{um}$ diameter) dominated in regions with low chlorophyll concentrations $\left(<1 \mu \mathrm{gl}^{-1}\right)$. About $30 \%$ of the mean nanoplankton carbon consisted of heterotrophic flagellates. Heterotrophic microplankton carbon (> 20 um diameter) was generally less significant. The variation in phytoplankton biomass was the result primarily of changes in cell density of pennate diatoms in the East Wind Drift, and of centric diatoms in the Weddell Sea and the Scotia Ridge region. Autotrophic and heterotrophic carbon as determined by microscopical analysis were compared with data for total particulate carbon, chlorophyll $a_{1}$ and adenosine triphosphate. Estimates for the $\mathrm{C}$ : chl ratio of autotrophs increased with decreasing concentrations of chlorophyll $a$, with mean values of 46 in bloom waters and 144 in 'blue water'. A C:ATP ratio for heterotrophic nanoplankton was estimated to be about 100, while that for heterotrophic microplankton may be lower. Algorithms, incorporating concentrations of chlorophyll a and ATP, are described which allow estimates of autotrophic and heterotrophic microbial biomass.
\end{abstract}

\section{INTRODUCTION}

The paradigm for the microbial food web in natural waters has undergone much change in recent years. It is now recognized that natural waters frequently contain sizable stocks of autotrophic picoplankton $(<2 \mu \mathrm{m})$ and nanoplankton ( 2 to $20 \mu \mathrm{m}$ ) eucaryotic organisms relative to that of the microplankton $(20$ to $200 \mu \mathrm{m})$ (Waterbury et al. 1979, Malone 1980, Johnson \& Sieburth 1982). These size categories also include a variety of microbial predators (Sieburth et al. 1978, Sorokin 1981, Fenchel 1982). From this knowledge, new conceptual models for the predator/prey relationships within microbial systems have been formulated (e.g. Azam et al. 1983, Hewes et al. 1985). However, our comprehension of microbial food webs is hindered because biomass (as carbon), differentiated in terms of trophic mode, cannot be determined with precision.

This paper deals with estimation of autotrophic and heterotrophic biomass on the basis of measurements of
C:chl and C:ATP ratios. Autotrophic and heterotrophic biomass are thus defined as organisms with and without chlorophyll $a$, respectively. Admittedly, this definition neglects the existence of trophic modes such as dasmotrophy (Estep \& MacIntyre 1989).

It is generally recognized that there is no single 'best method' to estimate biomass for oceanic microbial populations. Microscopical methods are slow and tedious, and often not suited for the large number of samples taken during the course of expeditions. In field studies, it is more common to estimate 'living' carbon as biomass by applying conversion factors to specific extracted biochemical components. Three such commonly used determinants of biomass are adenosine triphosphate (ATP), chlorophyll (chl) and particulate organic carbon (POC). Measurements of particulate organic carbon include variable amounts of detrital contamination so the biologically active constituents may be preferred.

Conversion factors which relate microbial carbon to 
chl, ATP or POC exhibit variation due to species composition and/or environmentally induced changes in physiological properties (Sakshaug \& Holm-Hansen 1977). The C:chl ratio of phytoplankton ranges from about 20 (Sullivan et al. 1983, Kiefer 1984, Geider et al. 1986) to greater than 100 (Redalje \& Laws 1981, Landry et al. 1984, Sakshaug et al. 1989). Both nutrient limitation and the light regime can cause the $\mathrm{C}$ :chl ratio to vary considerably (Shuter 1979, Kiefer \& Mitchell 1983 , Laws et al. 1985, Geider \& Platt 1986, Sakshaug et al. 1989). For most natural populations, the influence of these factors upon the $\mathrm{C}: \mathrm{chl}$ ratio is not known. This problem is particularly pronounced in the Southern Ocean where, although nutrients are thought not to be limiting, the light regime is extremely variable, and a wide range of $\mathrm{C}$ :chl values has been reported (Sakshaug 1989).

Estimates of microbial carbon based on ATP measurement usually invoke a C:ATP factor of 250, which appears to be adequate for multispecies communities of natural phytoplankton (Holm-Hansen 1970, Sakshaug \& Holm-Hansen 1977, Karl 1980). However, marine zooplankton may have lower C:ATP ratios (Karl 1980, Skjoldal 1981, Verity \& Langdon 1984). Thus total microbial carbon may be overestimated if the ratio of 250 is used (Eppley et al. 1978). Measurements of POC set an upper limit for living biomass and may commonly represent a gross overestimation.

Microscopical analysis can yield detailed information on both autotrophic and heterotrophic carbon. Because ATP and chl are used extensively to estimate microbial carbon, it is important to evaluate the variation in such estimates against the independent estimates provided by microscopical analysis to find out if simple algorithms based on commonly used parameters can be generated for partitioning of microbial carbon. The present work pertains to the biomass structure for populations of microbial eucaryotes found during summer in the Southern Ocean pelagial; the general methodological approach should be relevant to marine waters in general.

\section{MATERIALS AND METHODS}

Data were obtained during 2 expeditions to the Antarctic: the VULCAN 6 expedition with RV 'Melville' during January 1981 (Holm-Hansen \& Foster 1981) and the ACDA expedition with USCGC Polar Star' during January-February 1983 (Holm-Hansen \& Chapman 1983). The VULCAN 6 expedition was near the Scotia Ridge between the South Orkney Islands and South Georgia. Samples were obtained at 0, 5, and/or $10 \mathrm{~m}$ by Niskin bottles. The ACDA expedition skirted the Antarctic continental shelf westward from

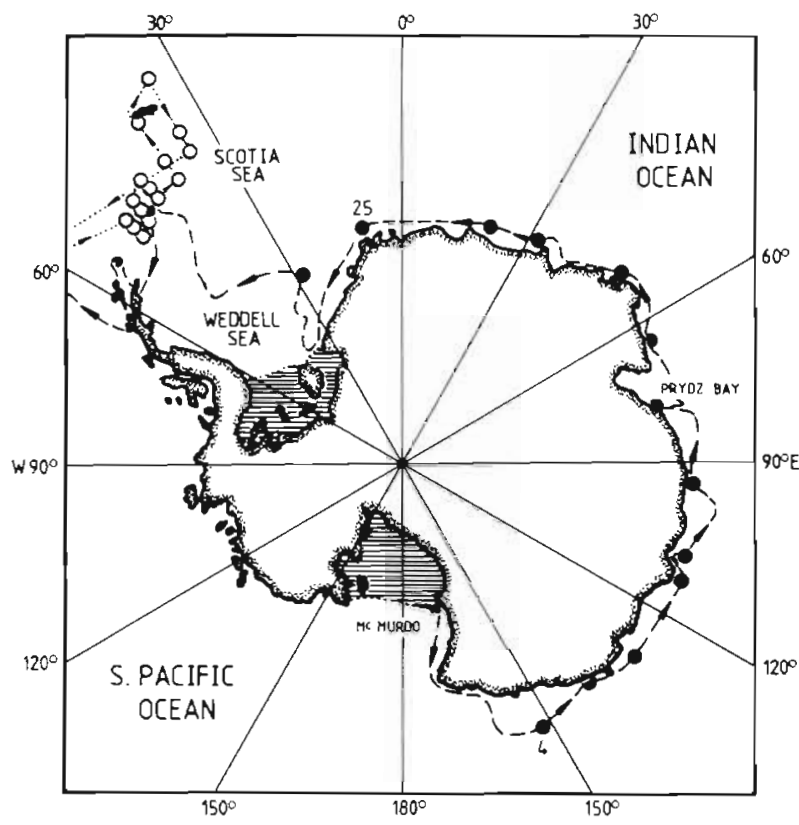

Fig. 1. Regions around the Antarctic continent which were covered by the VULCAN expedition, 1981 (dotted lines), and the ACDA expedition, 1983 (dashed lines). (o) VULCAN stations, (-) ACDA stations, from which data discussed in this paper were obtained

McMurdo Station to Palmer Station (Fig. 1). Water samples were obtained from the surface by bucket while the ship was under way. The data sets presented here are restricted to those which include microscopical analysis and all chemical analyses. Our study thus characterizes microbial communities in the upper euphotic zone over a large segment of the continental shelf of Antarctica in addition to some deep water areas of the Southern Ocean.

Chl a was measured fluorometrically in $100 \%$ methanol extracts (Holm-Hansen et al. 1965, HolmHansen \& Riemann 1978). ATP was extracted in boiling Tris buffer and determined by bioluminescence (HolmHansen \& Booth 1966). POC was determined with a Hewlett Packard elemental analyzer (Sharp 1974).

All samples were screened by a $202 \mu \mathrm{m}$ Nitex mesh to remove net-zooplankton. During the ACDA expedition, half of each sample was also screened by a $20 \mu \mathrm{m}$ Nitex mesh to remove microplankton. All estimates for concentrations contained in the microplankton fraction were obtained by subtracting that of the $<20 \mu \mathrm{m}$ fraction from the $<202 \mu \mathrm{m}$ fraction. Samples for chemical analysis were filtered onto Whatman GF/C glass fiber filters.

Independent tests on GF/C and GF/F filters in replicate water samples showed that 95 to $100 \%$ of the chl was retained by the GF/C filters. However, we assume that bacterial contamination of samples on GF/C filters was insignificant, based on earlier tests (Azam \& Hod- 
son 1977, Fuhrman \& Azam 1980) and the knowledge that the contribution of ATP from free-living bacteria in Antarctic waters may be about $10 \%$ of the total microbial ATP (Hodson et al. 1981).

Microscopical analysis was carried out using 2 different methods: (1) the Filter-Transfer-Freeze (FTF) technique (Hewes \& Holm-Hansen 1983, Hewes et al. 1984), and (2) the inverted microscope technique of Utermöhl (1958) as applied by Reid (1983). Nanoplankton samples for FTF were fixed with $0.5 \%$ glutaraldehyde (final dilution) for 5 to $10 \mathrm{~min}$, washed with $0.2 \mu \mathrm{m}$ filtered seawater, and stained with $4^{\prime}, 6$-diamidino-2-phenylindole-2-HCl (DAPI). After removal of the Nuclepore filter, the preparations were stored in the dark at less than $-10^{\circ} \mathrm{C}$ until examination (within $24 \mathrm{~h}$ ). For examination, the samples were embedded in gelatin, thawed, and examined for both DAPI-stained nuclei and chlorophyll using combined epifluorescence/phase contrast microscopical technique (see Hewes et al. 1984).

Replicate samples of the $<202 \mu \mathrm{m}$ fraction were preserved with $4 \%$ formalin for inverted microscope analysis. This size fraction was also examined using the FTF technique (above) for determination of the trophic mode of organisms not observed in the $<20 \mu \mathrm{m}$ fraction. The relative abundance and taxonomic description obtained from this FTF analysis was used to extrapolate trophic mode of microplankton of the formalin-preserved material. Microscopical analysis of water samples from the VULCAN expedition relied on the inverted microscope technique as the FTF technique had not yet been developed. For these, cells were assumed to be autotrophic if the trophic mode could not be taxonomically determined.

Nanoplankton biomass for the ACDA expedition was estimated by calculating plasma volumes (Strathmann 1967) from the dimensions and shapes of cells and vacuoles as observed with phase contrast microscopy (FTF). The conversion factor used $\left(\mathrm{pg} \mathrm{C}=0.11 \times \mu \mathrm{m}^{3}\right.$ plasma volume) is reasonable because low concentrations of glutaraldehyde and brief fixation periods should not significantly shrink cytoplasm (Børsheim \& Bratbak 1987). In contrast, biomass was estimated from the formalin-preserved water samples (all VULCAN samples and the microplankton of the ACDA samples) by a combination of equations described by Strathmann (1967; diatom and naked flagellate) and Beers et al. (1975; protozoan). Although this method of estimating cell carbon from formalin-fixed material appears appropriate (Reid 1983, Verity \& Langdon 1984, Borsheim \& Bratbak 1987), the density of cells less than $5 \mu \mathrm{m}$ diameter will be underestimated (Hewes et al. 1984). It was also difficult to distinguish between autotrophic and heterotrophic flagellates in these formalinpreserved samples. As unidentified flagellates of the
VULCAN samples were considered 'autotrophic', this compensated somewhat for underestimated densities of the photosynthetic forms, but did result in low estimates of heterotrophic nanoplankton.

\section{RESULTS}

In general, waters containing $<1 \mu \mathrm{g}$ chl $\mathrm{l}^{-1}$ ('blue water') were dominated by nanoplankton (i.e. $>50 \%$ of the autotrophic biomass), while waters containing $>2 \mu \mathrm{g} \mathrm{chl} \mathrm{I}^{-1}$ were dominated by microplankton (Table 1). Phycoerythrin-containing procaryotes were not observed during the ACDA expedition, but a small number of picoplankton eucaryotes $(1$ to $2 \mu \mathrm{m}$ diameter, well-defined nuclei) were observed. Elevated chlorophyll concentrations resulted from increases of diatom biomass (Table 1). In the Scotia Sea, these increases were mainly due to centric diatoms; in the East-Wind Drift (ACDA Stns 4 to 25, Fig. 1) they were due to pennate diatoms. Autotrophic flagellates also appeared as a more important component of the VULCAN samples than of the ACDA samples. In spite of different microscopical methods to obtain microbial biomass, estimates of autotrophic carbon relative to ranges of chlorophyll concentration were similar for both ACDA and VULCAN expeditions.

Data in Tables 2, 3, and 4 represent mean values of biomass carbon and biomass determinants (chl, ATP, and $\mathrm{POC}$ ). In Table 2, the blue water data from the East-Wind Drift is categorized with respect to the nanoplankton and microplankton size fractions. In Table 3 , the values for all $<202 \mu \mathrm{m}$ samples are presented. In Table 4 , the data of Table 3 have been partitioned into groups according to chlorophyll concentration.

In the East-Wind Drift, all but 2 stations had chlorophyll concentrations less than $1 \mu \mathrm{g} \mathrm{l} \mathrm{l}^{-1}$. A small (1 to $2 \times 3$ to $4 \mu \mathrm{m}$ ) pennate diatom, Nitzschia pseudonana Hasle, dominated in terms of carbon, a finding similar to that described by Hasle (1969). For these stations, we found that on average $86 \%$ of the $\mathrm{POC}$, $78 \%$ of the total microbial carbon $\left(\mathrm{C}_{\mathrm{t}}\right), 76 \%$ of the $\mathrm{chl}$, and $61 \%$ of the ATP $\left(\mathrm{ATP}_{\mathrm{t}}\right)$ passed through a $20 \mu \mathrm{m}$ screen (Table 2). More than $90 \%$ of the $<20 \mu \mathrm{m}$ chl and ATP fractions passed through a $10 \mu \mathrm{m}$ screen (data not presented). The highest chl concentration along the East-Wind Drift route was found in Prydz Bay $(2.32 \mu \mathrm{g}$ $\left.\mathrm{l}^{-1}\right)$. At this station, $N$. pseudonana dominated the phytoplankton population, contributing $42 \%$ of the autotrophic nanoplankton carbon. This station was near shore, and is thus not considered in the data presented in the tables or discussion.

Heterotrophic carbon $\left(C_{h}\right)$ represented on average $30 \mu \mathrm{g} \mathrm{I}^{-1}$ (44\% of total eucaryotic microbial carbon) in the East Wind Drift, and $84 \%$ of the eucaryotic hetero- 
Table 1 Average microbial biomass classified to autotrophic and heterotrophic cells and taxonomic description as found for the VULCAN expedition (<202 $\mu \mathrm{m}$ water samples) and for the ACDA expedition (<20 $4 \mathrm{~m}$ and 20 to $202 \mu \mathrm{m}$ screened water samples). Total values represent sums of the averages. These values have been grouped into ranges of chl concentration to show trends in the transformation of trophic structure from low to high chl values

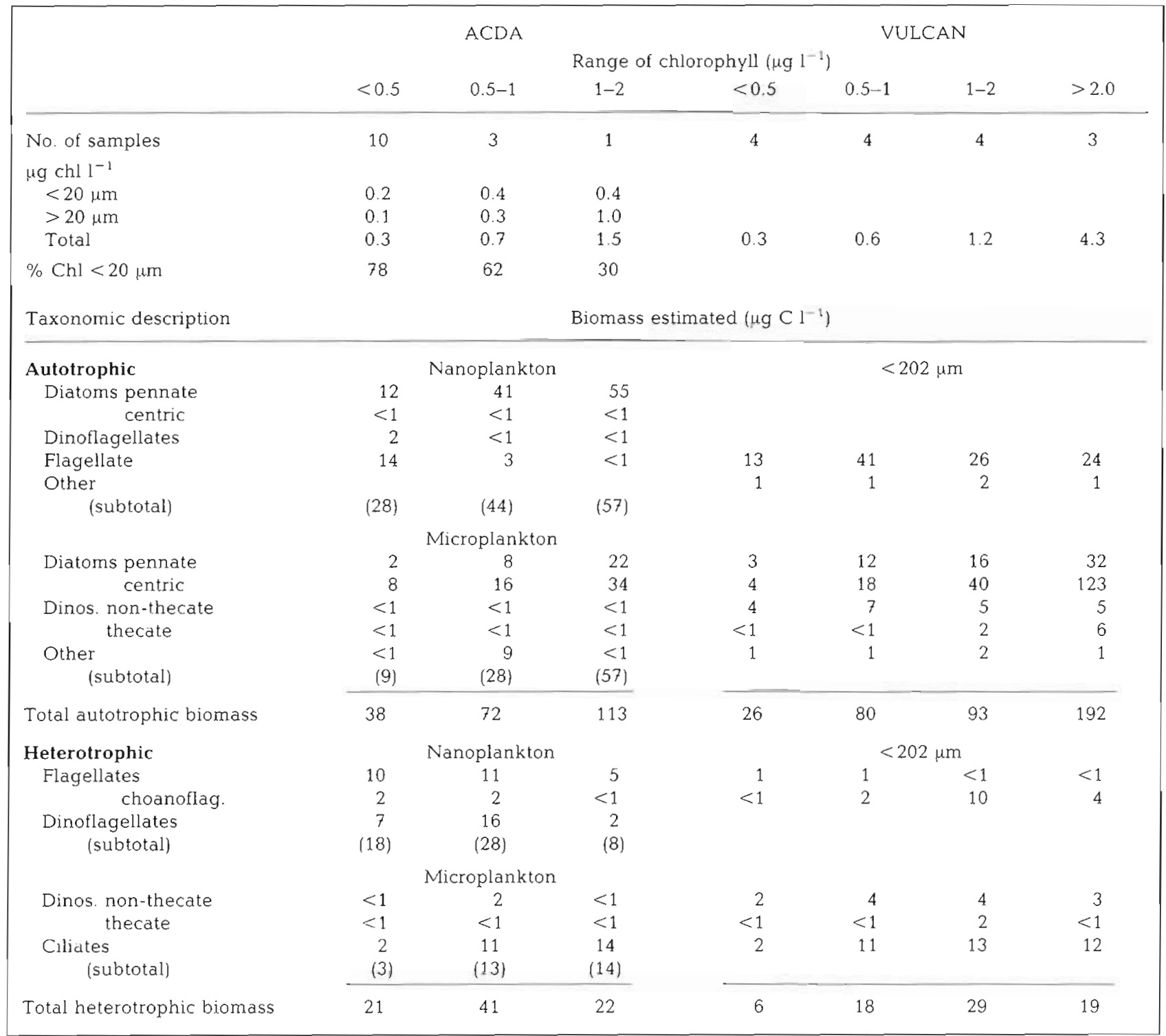

trophic microbial biomass was nanoplankton (Table 2 ). The average protozoan biomass for both the ACDA and VULCAN expeditions was $23 \%$ of the entire microbial population (Table 3). The most common ciliate was Laboea conica Lohmann, and most common dinoflagellates were Amphidinium hadai Balech, and Gyrodinium lachryma (Meunier) Kofoid \& Swezy. In our samples, these dinoflagellates lacked chloroplasts, although they have been described as autotrophic (Balech 1976).

Autotrophic carbon $\left(\mathrm{C}_{a}\right)$ and total microbial carbon $\left(C_{1}\right)$ estimates determined by microscopical analysis were less than, but covaried with fluctuations in POC
(Tables 2 to 4 ). We therefore conclude that microscopical analysis yielded reasonable values for biomass. As can be obtained from Table 2, mean $C$ :chl values differed little between the nanoplankton (114) and the microplankton (122). The mean $\mathrm{C}_{\mathrm{a}}$ : chl ratio for the entire ACDA expedition was 137, in contrast to 88 for the Vulcan expedition (Table 3).

In general, data presented for both of the ACDA size fractions (Table 2) and total microbial values (Table 3) indicate that biomass derived from a C:ATP ratio of 250 $\left(C_{a t p}\right)$ was considerably higher than $C_{t}$, and in fact, often exceeded the POC values. For the ACDA nanoplankton, the mean $C_{\text {atp }}$ ratio was $85 \%$ of the mean 
Table 2. Mean particulate chemical concentrations and microbial biomasses of nanoplankton and microplankton obtained by size fractioning found for 12 'blue water' stations along the East Wind Drift (Stns 4 to 23; Fig. 1) during the ACDA expedition. Biomass ( $\mathrm{ug} \mathrm{C}^{-1}$ ) was estimated through microscopical methods and differentiated as autotrophic $\left(C_{a}\right)$, heterotrophic $\left(C_{h}\right)$ and total $\left(C_{h}\right)$. Particulate organic carbon (POC), chlorophyll (chl), and adenosine triphosphate (ATP) are in $\mu \mathrm{g} \mathrm{l}^{-1}$. Total microbial biomass in $\mu \mathrm{g} \mathrm{Cl^{-1 }}$ as from ATP data $\left(C_{a 1 p}=250 \times A T P\right)$ and from Eq. (5) $\left(e s t C_{l}\right)$. The ratios in Tables 2 to 4 represent the mean ratio of the weights, and cannot be derived by ratioing the mean values listed in the tables

\begin{tabular}{lcc|}
\hline Parameter & Nanoplankton & Microplankton \\
\hline $\mathrm{C}_{\mathrm{cl}}$ & $32 \pm 22$ & $11 \pm 10$ \\
$\mathrm{C}_{\mathrm{h}}$ & $26 \pm 11$ & $4 \pm 3$ \\
$\mathrm{C}_{\mathrm{l}}$ & $58 \pm 21$ & $15 \pm 11$ \\
POC & $95 \pm 25$ & $15 \pm 12$ \\
Chl & $0.28 \pm 0.14$ & $0.09 \pm 0.10$ \\
ATP & $0.33 \pm 0.10$ & $0.21 \pm 0.21$ \\
$\mathrm{C}_{\mathrm{atp}}$ & $81 \pm 24$ & $52 \pm 54$ \\
estC & $52 \pm 16$ & $27 \pm 26$ \\
Chl $_{\mathrm{t}}$ ATP & $0.83 \pm 0.24$ & $0.54 \pm 0.59$ \\
$\mathrm{C}_{\mathrm{a}}: \mathrm{C}_{\mathrm{t}}$ & $0.58 \pm 0.20$ & $0.72 \pm 0.15$ \\
\hline
\end{tabular}

Table 3. Mean values of total microbial biomass, particulate chemical composition, and derived ratios from both the VULCAN and ADCA expeditions. Autotrophic biomass as estimated from chl by the non-linear $C$ : chl relationship. est $\mathrm{C}_{a}$ : chl, in Eq. (3) is shown as est $\mathrm{C}_{\mathrm{c}}$. All other units and terms as described in the caption for Table 2

\begin{tabular}{|c|c|c|c|}
\hline Parameter & $\mathrm{ACDA}$ & VULCAN & $\begin{array}{l}\text { ACDA plus } \\
\text { VULCAN }\end{array}$ \\
\hline $\begin{array}{l}\text { Number of } \\
\text { samples }\end{array}$ & 14 & 15 & 29 \\
\hline $\mathrm{C}_{a}$ & $51 \pm 28$ & $101 \pm 76$ & $78 \pm 64$ \\
\hline $\mathrm{C}_{\mathrm{h}}$ & $30 \pm 16$ & $17 \pm 17$ & $23 \pm 18$ \\
\hline$C_{1}$ & $81 \pm 29$ & $119 \pm 79$ & $101 \pm 64$ \\
\hline $\mathrm{POC}$ & $118 \pm 37$ & $197 \pm 142$ & $160 \pm 114$ \\
\hline Chl & $0.45 \pm 0.35$ & $1.82 \pm 2.32$ & $1.18 \pm 1.84$ \\
\hline ATP & $0.55 \pm 0.29$ & $0.92 \pm 0.73$ & $0.75 \pm 0.60$ \\
\hline $\mathrm{C}_{\mathrm{a} 1 \mathrm{p}}$ & $137 \pm 72$ & $231 \pm 183$ & $187 \pm 150$ \\
\hline est $\mathrm{C}_{\mathrm{t}}$ & $83 \pm 38$ & $133 \pm 97$ & $119 \pm 95$ \\
\hline est $C_{a}$ & $47 \pm 20$ & $98 \pm 74$ & $74 \pm 61$ \\
\hline chl : ATP & $0.82 \pm 0.35$ & $1.53 \pm 0.76$ & $1.20 \pm 0.70$ \\
\hline $\mathrm{C}_{\mathrm{a}}: \operatorname{chl}$ & $137 \pm 63$ & $88 \pm 35$ & $111 \pm 55$ \\
\hline est $\mathrm{C}_{\mathrm{d}}: \mathrm{chl}$ & $123 \pm 28$ & $91 \pm 41$ & $106 \pm 39$ \\
\hline
\end{tabular}

Table 4. Mean values for the $<202 \mu \mathrm{m}$ microbial fraction of the combined VULCAN and ACDA expeditions (last column, Table 3) categorized into ranges of $\mathrm{chl}$ concentration. The mean values of est $\mathrm{C}_{\mathrm{a}}$ : chl and $\mathrm{C}_{\mathrm{a}}$ : chl for each range in chl concentration are given. For all terms and units, see captions of Tables 2 and 3

\begin{tabular}{|c|c|c|c|c|}
\hline \multirow[t]{2}{*}{ Parameter } & \multicolumn{4}{|c|}{ Range in chlorophyll concentration, $\mu l^{-1}$} \\
\hline & Chl $<0.5$ & $0.5<\mathrm{Chl}<1.0$ & $1.0<\mathrm{Chl}<2.0$ & $\mathrm{Chl}>2.0$ \\
\hline No. of samples & 14 & 7 & 5 & 3 \\
\hline $\mathrm{C}_{\mathrm{a}}$ & $34 \pm 12$ & $77 \pm 29$ & $102 \pm 26$ & $190 \pm 79$ \\
\hline$C_{n}$ & $21 \pm 16$ & $28 \pm 20$ & $27 \pm 19$ & $19 \pm 10$ \\
\hline$C_{1}$ & $55 \pm 20$ & $105 \pm 36$ & $129 \pm 24$ & $209 \pm 110$ \\
\hline est $\mathrm{C}_{\mathrm{a}}$ & $36 \pm 8$ & $62 \pm 8$ & $93 \pm 6$ & $186 \pm 57$ \\
\hline est $C_{1}$ & $57 \pm 14$ & $118 \pm 29$ & $136 \pm 16$ & $287 \pm 105$ \\
\hline $\mathrm{POC}$ & $94 \pm 27$ & $129 \pm 25$ & $187 \pm 38$ & $373 \pm 84$ \\
\hline Chl & $0.27 \pm 0.10$ & $0.65 \pm 0.15$ & $1.28 \pm 0.13$ & $4.29 \pm 2.19$ \\
\hline ATP & $0.36 \pm 0.12$ & $0.81 \pm 0.26$ & $0.80 \pm 0.13$ & $1.76 \pm 0.72$ \\
\hline estC $C_{a}:$ chl & $136 \pm 57$ & $116 \pm 36$ & $79 \pm 19$ & $48 \pm 5$ \\
\hline $\mathrm{C}_{a}: \mathrm{chl}$ & $144 \pm 22$ & $96 \pm 8$ & $73: 3$ & $46 \pm 5$ \\
\hline Chl : ATP & $0.82 \pm 0.38$ & $0.87 \pm 0.21$ & $1.62 \pm 0.16$ & $2.42 \pm 0.44$ \\
\hline$C_{a}: C_{t}$ & $0.65 \pm 0.17$ & $0.74 \pm 0.19$ & $0.79 \pm 0.13$ & $0.89 \pm 0.09$ \\
\hline
\end{tabular}

POC (a difference of $14 \mu \mathrm{g} \mathrm{I}^{-1}$ ), while $\mathrm{C}_{\mathrm{atp}}$ of the combined Vulcan and ACDA data was $117 \%$ of the mean total POC (27 $\mu \mathrm{g} \mathrm{l}^{-1}$ higher). Thus, although the mean $\mathrm{C}_{\mathrm{atp}}$ of the nanoplankton tended to give values slightly less than mean POC, total $\mathrm{C}_{\text {atp }}$ overestimated POC and this is clearly unreasonable. In contrast, the mean $C_{t}$ was $54 \%$ of the POC for the ACDA nanoplankton and $67 \%$ of the POC for the ACDA total microbial stocks.

The cellular C:ATP ratio of 250 appears realistic for natural phytoplankton communities (Holm-Hansen 1970, Sakshaug \& Holm-Hansen 1986), especially for conditions existing in the Antarctic (Karl 1980). However, the heterotrophic biomass found for the ACDA samples averaged $33 \%$ of the total nanoplankton biomass (14 stations). Therefore a higher concentration of ATP for heterotrophs would make a large difference in total microbial biomass estimates based on ATP (Banse 1980, Karl 1980, Skjoldal 1981, Verity \& Langdon 

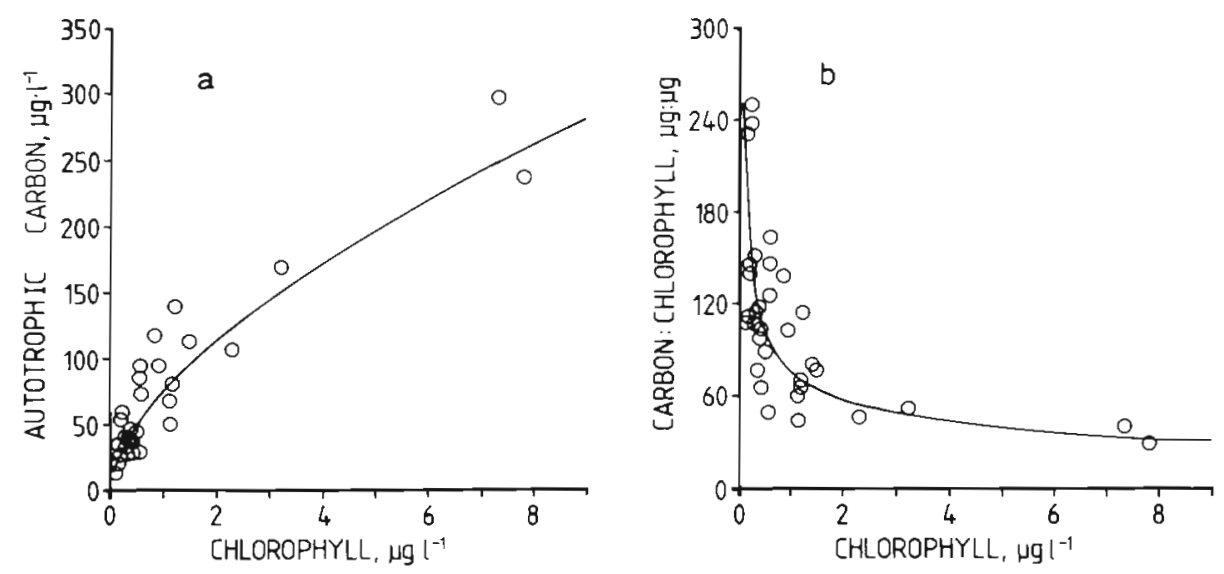

Fig. 2. Relationship between chlorophyll $a$ and phytoplankton carbon in the Southern Ocean. (a) Relationship between autotrophic carbon ( $\mu g \mathrm{C}^{-1}$, determined microscopically) and chlorophyll ( $\mu \mathrm{g} \mathrm{chl} 1^{-1}$ ), as described in the text. (b) Same regression as in (a), but autotrophic carbon divided by chlorophyll to demonstrate the non-linear relationship between C:chl and chl

1984). We used the following equation to estimate the C:ATP ratio for heterotrophic nanoplankton $\left(\mathrm{C}_{h_{n}}: \mathrm{ATP}_{\mathrm{hn}}\right)$ in our material:

$$
\left.\mathrm{C}_{\mathrm{hn}}: \mathrm{ATP}_{\mathrm{hn}}=\mathrm{C}_{\mathrm{hn}} / \mathrm{ATP}_{\mathrm{n}}-\left(\mathrm{C}_{\mathrm{an}} / 250\right)\right]
$$

where $\mathrm{ATP}_{\mathrm{n}}=$ total nanoplankton concentration, given as $\mu \mathrm{g} \mathrm{l}^{-1} ; \mathrm{C}_{\mathrm{an}}$ and $\mathrm{C}_{\mathrm{hn}}=$ autotrophic and heterotrophic

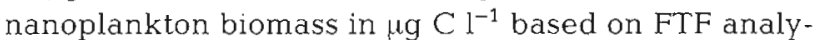
sis. This yielded a mean value of about 100 ( $\mathrm{n}=14$, $\mathrm{C}_{\mathrm{hr}}: \mathrm{ATP}_{\mathrm{hn}}=106 \pm 55$ ). This is similar to values for marine zooplankton (Skjoldal \& Båmstedt 1977, Karl et al. 1978, Skjoldal 1981), although higher than that reported for tintinnids (Verity \& Langdon 1984).

It is evident that phytoplankton biomass $\left(\mathrm{C}_{a}\right)$ and chl concentration did not have a linear relationship (Table 4). Furthermore, the small variation in the $C_{a}: C_{t}$ ratio implies that the contribution of heterotrophic ATP cannot entirely explain the large variation found in the chl:ATP ratio over the range of chlorophyll concentrations we examined (Table 4). The relationship between autotrophic carbon and chl concentration can be described as an empirical function:

$$
\mathrm{C}_{\mathrm{a}}=80 \mathrm{chl}^{0.6}
$$

( $n=33, r^{2}=0.8$; Fig. 2a). Values of autotrophic biomass as estimated in Eq. (2) (est $\mathrm{C}_{\mathrm{a}}$ ) are presented in Tables 3 and 4 where they may be compared with the other biomass determinants. It follows that the $\mathrm{C}$ :chl ratio (est $\mathrm{C}_{\mathrm{a}}:$ chl) is related to chlorophyll concentration by the function:

$$
\text { est } \mathrm{C}_{\mathrm{a}}: \mathrm{chl}=80 \mathrm{chl}^{-0.4}
$$

as demonstrated in Fig. $2 b$

The mean $\mathrm{C}$ :chl ratios (both $\mathrm{C}_{\mathrm{a}}$ :chl and est $\mathrm{C}_{\mathrm{a}}$ : chl) for various ranges of chlorophyll concentration are presented in Table 4 . The non-linearity of est $\mathrm{C}_{\mathrm{a}}$ :chl is also implied by comparing POC:ATP and POC:chl ratios (which can be estimated from the data presented in Table 4) for different concentrations of chl. The POC:ATP ratio is about the same for the lowest and highest concentrations of chl (POC:ATP about 240), whereas the POC:chl ratio varies from 87 to 348 .

\section{DISCUSSION}

Many important answers related to pelagic microbial systems depend upon realistically differentiated estimates of microbial biomass. Traditionally, biomass has been estimated by assuming constant either $\mathrm{C}$ : chl or C:ATP ratios (Eppley 1972, Holm-Hansen et al. 1977). Constant ratios may lead to erroneous biomass estimates. We have demonstrated that both ratios vary, but in a fairly predictable fashion. From our data, algorithms may be derived to provide improvements over previous methods for the estimation of microbial carbon, at least for the conditions which exist during summer in the Antarctic.

The heterotrophic C:ATP ratio of 100 was estimated from biomass and ATP of nanoplankton obtained during the ACDA expedition. Our estimates of nanoplankton carbon were based on plasma volumes derived by microscopical analysis, and therefore this ratio would resemble 'cytoplasmic' values. Our ratio is in the range of values generally ascribed to multicellular marine zooplankton (26 to 125; see Karl 1980, Skjoldal 1981, references cited therein), but is higher than that of about 65 obtained for tintinnids (Verity \& Langdon 1984). These data support Skjoldal's (1981) data, which implied that 'animal' (including protozoan) C:ATP values for various groups of zooplankton should vary within similar ranges, because the ratio is independent of the size of the organism.

It should be emphasized, however, that our data suggest a C:ATP value for some unicellular heterotrophic eucaryotes of less than 100. Comparison of $C_{a}: C_{t}$ and chl:ATP ratios of size-fractioned samples (Table 2) indicates that, since the C:chl ratios were nearly the same, the heterotrophic microplankton had a much lower C:ATP ratio than the nanoplankton. 
Ratios of C:ATP for the entire heterotrophic microbial population ranged from 33 (VULCAN) to 87 (ACDA), and thus were more similar to the value of 65 found for tintinnids (Verity \& Langdon 1984). We place more confidence, however, in our estimate of $C_{h}$ : ATP $P_{h}$ for nanoplankton from the ACDA expedition than for the formalin-preserved samples, because the method used to estimate carbon was more precise.

The differences in the C:ATP ratio for algae (250 to 286 ), bacteria (250 to 500 ) and zooplankton (40 to 125 ) may reflect the amounts of storage and structural carbon in the cells (Karl 1980). It is also likely that the C:ATP value for microbial heterotrophs of different size may vary with physiological status and the amount of structural carbon (e.g. scales, thecae or loricae).

The C:chl ratio of Antarctic blue waters (mean est $\mathrm{C}_{\mathrm{a}}: \mathrm{chl}=91$ to 123 ) is similar to values reported for other oligotrophic regions (Redalje \& Laws 1981, Landry et al. 1984). This ratio approaches, however, about 30 in offshore Antarctic waters with high chl concentrations (Fig. 2b), and is similar to that reported for Antarctic ice algae (Sullivan et al. 1983) and coastal Antarctic blooms (Sakshaug 1989). The non-linearity of the relationship between the $\mathrm{C}$ :chl ratio and the chl concentration may reflect adaptation of phytoplankton to different light regimes which may result from differences in the rate and depth of vertical mixing, and/or different photoadaptational strategies of communities (El-Sayed \& Mandelli 1965, Sakshaug \& Holm-Hansen $1984,1986)$. It is also possible that variations in the C:chl ratio may arise from the asymmetry of the photoadaptational response (i.e. from light to shade vs from shade to light) in deeply mixed water columns and from self-shading (Lewis et al. 1984, Geider \& Platt 1986, Cullen \& Lewis 1988).

Heterotrophic and autotrophic carbon may be estimated from data for chl and ATP concentrations. By rearrangement of Eq. (1) and using a value of 100 for the C:ATP ratio of heterotrophs, heterotrophic biomass may be estimated as:

$$
\text { est } \mathrm{C}_{\mathrm{h}}=\left[\mathrm{ATP}_{\mathrm{t}}-\mathrm{C}_{\mathrm{a}} / 250\right] \times 100
$$

Since autotrophic biomass can be estimated from chlorophyll concentration (Eq. 2), total microbial biomass can be estimated:

$$
\text { est } \mathrm{C}_{\mathrm{t}}=80 \mathrm{chl}^{0.6}+\left[\mathrm{ATP}_{\mathrm{t}}-\left(80 \mathrm{chl}^{0.6} / 250\right)\right] \times 100
$$

where est $\mathrm{C}_{\mathrm{t}}, \mathrm{ATP}_{\mathrm{t}}$, and $\mathrm{chl}=$ concentrations in $\mu \mathrm{gl}^{-1}$; and the constants of 250 and $100=\mathrm{C}$ :ATP ratios of autotrophic and heterotrophic eucaryotes, respectively. Table 2 indicates that est $\mathrm{C}_{\mathrm{t}}$ is reasonably close to nanoplankton carbon, but does overestimate microplankton carbon slightly.

It has been suggested that the ratio between chl and adenylate pools might index the trophic structure of microbial communities (Chiaudani \& Pagnotta 1978, Campbell et al. 1979). Our study indicates, however, that the chl:ATP ratio is a complex function not only of variation in the proportion of autotrophic biomass and changes in the cellular chl concentration of the phytoplankton, but also possible differences in size-fractioned heterotrophic C:ATP ratios (micro $<$ nano $<$ bacteria).

Estimations of algal biomass, whether on the basis of chl or ATP multiplied by certain factors, or on the basis of algorithms such as those presented here, represent a grossly simplified view of the pelagic ecosystem; species composition and differences in strategies between species are neglected. Yet simple algorithms are necessary for modeling of planktonic ecosystems on a regional or global scale. Presently-used methods for estimation of biomass carbon suffer for a variety of well-published reasons. The present algorithms for determination of autotrophic and heterotrophic carbon should in principle represent an improvement relative to earlier approaches while still being simple. The coefficients presented here are, however, specified only for a given region and time of the year. The ratios between microbial carbon, chlorophyll and ATP do vary, but the degree to which this occurs may be a function of environmental conditions. Variations in the C:chl ratio are, however, covered by the present algorithms, and to some extent variation in some ratios may be smoothed out by the presence of several species, for instance the C:ATP ratio of algae. Algorithms such as the present ones might therefore relate physical events occurring in the euphotic zone to biochemical and physiological characteristics of the microbial plankton.

Acknowledgements. This work was supported by US National Science Foundation grants DPP 79-21 295 and DPP 82-12 362, the Norwegian Research Council for Science and the Humanities, and the Norwegian Polar Institute. The authors thank J. R. Beers for helpful discussions and I. Dundas, F. Thingstad, and K. Y Børsheim for reviewing the manuscript.

\section{LITERATURE CITED}

Azam, F., Hodson, R. E. (1977). Size distribution and activity of marine microheterotrophs. Limnol. Oceanogr. 22: 492-501

Azam, F., Fenchel, T., Field, J. G., Gray, J. S., Meyer-Reil, L. A., Thingstad, T. F. (1983). The ecological role of water column microbes in the sea. Mar. Ecol. Prog. Ser. 10:257-263

Balech, E. (1976). Clave ilustrada de dinoflagelados Antárticos. Publ. 11, Instituto Antártico Argentino, Buenos Aires

Banse, K. (1980). Microzooplankton interference with ATP estimates of plankton biomass. J. Plankton Res. 3: 235-238

Beers, J. R., Reid, F. M. H., Stewart, G. L. (1975). Microplankton of the North Pacific Central Gyre. Population structure and abundance, June 1973. Int. Revue ges. Hydrobiol. 60: $607-638$

Børsheim, K. Y., Bratbak, G. (1987). Cell volume to cell carbon 
conversion factors for a bacterivorous Monas sp. enriched from seawater Mar Ecol. Prog. Ser, 36: 171-175

Campbell, W B., Jacobsen, I R., Pomeroy, L. R. (1979). Heterotrophic-photoautotrophic index: a qualitative parameter of microbial interactions applied to a Gulf Stream. intrusion. Mar Sci. Communs 5: 383-398

Chiaudani, B., Pagnotta, R. (1978). Ratio of ATP/chlorophyll as an index of rivers' water quality. Verh. int. Verein. Limnol. 20: $1897-1901$

Cullen, J. J., Lewis, M. R. (1988). The kinetics of algal photoadaptation in the context of vertical mixing. J. Plankton Res. 10: 1039-1063

El-Sayed, S. Z., Mandelli, E. P. (1965). Primary production and standing crop of phytoplankton in the Weddell Sea and Drake Passage. In: Biology of the Antarctic Seas II. American Geophysical Union, Washington, D.C., p. 87-106

Eppley, R. W. (1972). Temperature and phytoplankton growth in the Sea. Fish Bull. U.S. 70: 1063-1081

Eppley, R. W., Harrison, W. G., Chisholm, S. W., Stewart, E. (1978). Particulate organic matter in surface waters off Southern California and its relationship to phytoplankton. J. mar Res. 35: 671-696

Estep, K. W., Macintyre, F. (1989). Taxonomy, life cycle, distribution and dasmotrophy of Chrysochromulina: a theory accounting for scales, haptonema, muciferous bodies and toxicity. Mar. Ecol. Prog. Ser. 57: 11-21

Fenchel, T (1982). Ecology of heterotrophic microflagellates. IV. Quantitative occurrence and importance as bacterial consumers. Mar. Ecol. Prog. Ser 9: 35-42

Fuhrman, J. A., Azam, F. (1980). Bacterioplankton secondary production estimates for coastal waters of British Columbia, Antarctica, and California. App. environ. Microbiol. 39: 1085-1095

Geider, R. J., Platt, T (1986). A mechanistic model of photoadaptation in microalgae. Mar. Ecol. Prog. Ser. 30: 85-92

Geider, R. J., Osborne, B. A., Raven, J. A. (1986). Growth, photosynthesis and maintenance metabolic cost in the diatom Phaeodactylum tricornutum at very low light levels. J. Phycol. 22: 39-48

Hasle, G. R. (1969). An analysis of the phytoplankton of the Pacific Southern Ocean: abundance, composition, and distribution during the Brategg expedition, 1947-1948. Hvalråd Skr. 52: 1-168

Hewes, C. D., Holm-Hansen, O. (1983). A method of recovering nanoplankton from filters for identification with the microscope: the filter-transfer-freeze (FTF) technique Limnol. Oceanogr 28: 389-394

Hewes, C. D., Holm-Hansen, O., Sakshaug, E. (1985). Alternate carbon pathways at lower trophic levels in the Antarctic food web. In: Siegfried, W. R., Condy, P. R., Laws, R. M. (eds.) Antarctic nutrient cycles and food webs. SpringerVerldy, Berlin, p. 277-283

Hewes, C. D., Reid, F. M. H., Holm-Hansen, O. (1984). The quantitative analysis of nanoplankton: a study of methods. J. Plankton Res. 6: 601-613

Hodson, R. E., Azam, F., Carlucci, A. F., Fuhrman, J. A., Karl, D. M., Holm-Hansen, O. (1981). Microbial uptake of dissolved organic matter in McMurdo Sound, Antarctica. Mar Biol. 61: 89-94

Holm-Hansen, O. (1970). ATP levels in algal cells as influenced by environmental conditions. Plant Cell Physiol. 11 : $689-700$

Holm-Hansen, O., Booth, C. R. (1966). The measurement of adenosine triphosphate in the ocean and its ecological significance. Limnol. Oceanogr 11: 510-519

Holm-Hansen, O., Chapman, A. S. (1983). Antarctic circumnavigation cruise, 1983. Antarctic J. U.S 18: 162-163
Holm-Hansen, O., El-Sayed, S. Z., Franceschini, G. A., Cuhel, R. L. (1977). Primary production and the factors controlling phytoplankton growth in the Southern Ocean. In: Llano. G. A. (ed.) Adaptations within Antarctic ecosystems. Gulf Publishing Co.. Houston, Texas, p. 11 jo

Holm-Hansen, O., Foster, T. D. (1981). A multidisciplinary study of the eastern Scotia Sea. Antarctic J. U.S. 18: 162-163

Holm-Hansen, O., Lorenzen, C. J., Holmes, R. W., Strickland, J. D. H. (1965). Fluorometric determination of chlorophyll. J. Cons. perm. int. Explor Mer 30: 3-15

Johnson, P. W., Sieburth, J. McN. (1982). In-situ morphology and occurrence of eucaryotic phototrophs of bacterial size in the picoplankton of estuarine and oceanic waters. J. Phycology 18: 318-327

Karl, D. M. (1980). Cellular nucleotide measurements and applications in microbial ecology. Microbiol. Rev. 44 : 739-796

Karl, D. M., Haugness, I. A., Campbell, L., Holm-Hansen, O (1978). Adenine nucleotide extraction from multicellular organisms and beach sand: ATP recovery, energy charge ratios and determination of carbon/ATP ratios. J. exp. mar. Biol. Ecol. 34: 163-181

Kiefer, D. A. (1984). A thermodynamic description of phytoplankton. In: Holm-Hansen, O., Bolis, L., Gilles, R. (eds.) Marine phytoplankton and productivity. Springer-Verlag, Berlin, p. 35-44

Kiefer, D. A., Mitchell, B. G. (1983). A simple, steady-state description of phytoplankton growth based on absorption cross section and quantum efficiency. Limnol. Oceanogr. 28: $770-776$

Landry, M. R., Haas, L. W., Fagerness, V L. (1984). Dynamics of microbial plankton communities: experiments in Kaneohe Bay, Hawaii. Mar. Ecol. Prog. Ser, 16: 127-133

Laws, E. A., Jones, D. R., Terry, K. L., Hirata, J. A. (1985). Modifications in recent models of phytoplankton growth: theoretical developments and experimental examination of predictions. J theor. Biol. 114: 323-341

Lewis, M. R., Cullen, J. J., Platt, T (1984). Relationships between vertical mixing and photoadaptation of phytoplank. ton: similarity criteria. Mar Ecol. Prog. Ser. 15: 141-149

Malone, I (1980). Algal size. In: Morris, I. (ed.) The physiological ecology of phytoplankton. Univ. California Press, Berkeley, p. 433-463

Redalje, D. G., Laws, E. A. (1981). A new method for estimating phytoplankton growth rates and carbon biomass. Mar Biol. 62: 73-79

Reid, F. M. H. (1983). Biomass estimation of components of the marine nanoplankton picoplankton by the Utermöhl settling technique. J. Plankton Res. 5: 235-252

Sakshaug, E. (1989). The physiological ecology of polar phytoplankton. In: Rey, L., Alexander, V (eds.) Proc. 6th Conf. Com. Arctique Int E. J. Brill, Leiden. p. 61-89

Sakshaug, E., Holm-Hansen, O. (1977). Chemical composition of Skeletonema costatum (Grev.) Cleve and Pavlova (Monochrysis) lutheri (Droop) Green as a function of nitrate, phosphate, and iron-limited growth. J. exp. mar Biol. Ecol. 29: 1-24

Sakshaug, E., Holm-Hansen, O. (1984). Factors governing pelagic production in polar oceans. In: Holm-Hansen, $O$.. Bolis, J., Gilles, R. (eds.) Marine phytoplankton and productivity. Springer-Verlag, Berlin, p. 1-18

Sakshaug, E., Holm-Hansen, O. (1986). Photoadaptation in Antarctic phytoplankton: variations in growth rate, chemical composition and P versus I curves. J. Plankton Res. 8: $459-473$

Sakshaug, E., Andresen, K., Kiefer, D. A. (1989). A steadystate description of growth and light absorption in the 
marine planktonic diatom Skeletonema costatum. Limnol. Oceanogr. 34: 198-205

Sharp, J. H. (1974). Improved analysis for 'particulate' organic carbon and nitrogen from seawater. Limnol. Oceanogr 19: $984-989$

Shuter, B. (1979). A model of physiological adaptation in unicellular algae. J. theor. Biol. 78: 519-552

Sieburth, J. McN., Smetacek, V., Lenz, J. (1978). Pelagic ecosystem structure: heterotrophic compartments of the plankton and their relationship to plankton size fractions Limnol. Oceanogr 23: 1256-1257

Skjoldal, H. R. (1981). ATP concentration and adenylate energy charge of tropical zooplankton from waters inside the Great Barrier Reef. Mar Biol. 62: 119-123

Skjoldal, H. R., Båmstedt, U. (1977). Ecobiochemical studies on the deep-water pelagic community of Korsfjorden, western Norway. Adenine nucleotides in zooplankton. Mar. Biol. 42: 197-211

Sorokin, Yu. 1. (1981). Microheterotrophic organisms in

This article was presented by Dr H. R. Skjoldal, Bergen, Norway marine ecosystems. In. Longhurst, A. (ed.) Analysis of marine ecosystems. Academic Press. London, p. 293-342

Strathmann, R. R. (1967). Estimating the organic carbon content of phytoplankton from cell volume or plasma volume Limnol. Oceanogr 12:411-418

Sullivan, C. W., Palmisano, A. C., Kottmeier, S., McGrath IN RUHErossi, S., Moe, R., Taylor, G. T (1983). The influence of light on development and growth of sea-ice microbial communities in McMurdo Sound. Antarctic J. U.S. 18 $177-179$

Utermöhl, H. (1958). Zur Vervollkommnung der quantitativen Phytoplankton-Methodik. Mitt. int. Verein. Limnol. 9: $1-38$

Verity, P. G., Langdon, C. (1984). Relationships between lorica volume, carbon, nitrogen, and ATP content of tintinnids in Narragansett Bay. J. Plankton Res. 6: 859-868

Waterbury, K. B., Watson, S. W., Guillard, R. R. L., Brand, L. E. (1979). Widespread occurrence of a unicellular marine planktonic cyanobacterium. Nature, Lond. 277: 293-299

Manuscript first received: January 7,1988

Revised version accepted: February 20, 1990 